\title{
Musharraf's Democracy and 2008 Elections in Pakistan
}

\author{
Dr. Zahoor Ahmed \\ Head of Political Science Department, Govt Islamia College Faisalabad, Pakistan \\ Email:zahoor707@gmail.com \\ Dr. Manzoor Khan Afridi \\ Head of Department of Politics and International Relations \\ International Islamic University Islamabad, Pakistan \\ Email:manzoor_s01@yahoo.com
}

\section{Doi:10.5901/mjss.2014.v5n14p474}

\begin{abstract}
Quest for a true and representative democracy in Pakistan has been a strong wish of the people. It was the civilian government as well as the military regime who promised for the establishment of a democratic culture in the country. The paper discusses general elections of 2008 in Pakistan with various trends, change and seats adjustment among different political parties. It was the election which wiped out the dictatorship and paved way for a new way of democracy. Pakistan People's Party emerged as a biggest political party to form governments in capital, Sindh province and a coalition government in NWFP, while Musharraf's favourite party PML (Q) faced failure in coming into power. An attempt has been made here to find out causes of the proMusharraf parties' failure by not winning a majority vote in the parliament. Also to discover that why PPP remained successful in the election? Paper is qualitative in nature having the descriptive-analytical format.
\end{abstract}

Keywords: Musharraf, PPP, Muslim League (N), Democracy, Election

\section{Introduction}

Election 2008 was scheduled by Pakistan Election Commission on 20 th November 2007 and it was briefed that General Election would be held on January 08, 2008. The Political observers argued that the General Election in Pakistan would be critical because after a long period of time genuine leadership was within the state. Musharraf was absolute clear that election in Pakistan would determine his future in Pakistan. Election discussion should be examined in Pre-Benazir death era and in post Benazir death area. As Benazir reached Pakistan after exile, she had to face two challenges e.g. National Reconciliation Ordinance (NRO Deal) and Charter of Democracy (Jill, 2007). Musharraf issued National Reconciliation Ordinance (NRO) to facilitate all those political leaders who had to face litigation related to maladministration and corruption charges and their cases were still pending. The tenure was fixed from 1988 to 1998. In this ordinance, all cases were declared null and void, simply provided clean sheet to maximum number of politicians. Everyone had received benefits from NRO. The political intellectuals and civil society members argued that said deal damaged Benazir Bhutto because she violated Charter of Democracy (Reuters, 2007). In this situation, Benazir Bhutto was asked for political bargaining with Mr. Musharraf through common friends and secret officials. In this matter, the resources informed that secret deal was staged between Musharraf and Benazir when Asif Ali Zardari was freed from jail in the result of a judgment, passed by Supreme Court. After nine years, Mr. Asif Ali Zardari was allowed to visit his family (Mazhar, 2005). NRO deal with Musharraf demised Benazir image in Pakistan. Signed document of Charter of Democracy was appreciable publically. So, Benazir was on two fold thinking. She had got rid of Musharraf as soon as Musharraf imposed emergency. Benazir challenged and launched Long March against his act. Now the question of democracy was again attached with political forces e.g. Benazir Bhutto and Mian Nawaz Sharif. Benazir, Mian Muhammad Nawaz Sharif and Ch. Pervaiz Elahi were main contester for next election. In the light of the $17^{\text {th }}$ Amendment, Benazir and Nawaz Sharif could not be candidate for Prime Minister ship for third term (Reuters, 2007). Mr. Pervaiz Elahi was sponsored candidate of Pervaiz Musharraf. For general election, Benazir and Nawaz Sharif had to be Member of Parliament. Now, the situation became more critical as Mian Nawaz Sharif's nomination (papers) were rejected by Election Commission. It was informed to Nawaz Sharif that his papers were rejected due to his convicted crimes and put up judicial judgments against him. MMA position was also weak due to differences between Qazi Hussain Ahmad and Mulana Fazal-u-Rehman. MMA 
played friendly opposition role earlier and its credibility had become question mark as opposition. It had been observed that, Mulana Fazal-u-Rehman favoured Musharraf silently because his political party was enjoying political status in Balochistan and NWFP. In this situation, it was difficult for Mulana to opt uncomfortable attitude with Musharraf. On the other hand, Qazi Hussain Ahmad's was ineffective role but remained directly associated with MMA. As political party, Muslim League ( $N$ ) did not have proper homework for coming election. Muslim League had short time to launch political campaign entirely. Only Punjab was properly scheduled by Muslim League (Nawaz) Group. Within Punjab now it had to face Muslim League (Q) Pro-Musharraf. In these circumstances, Mr. Qazi Hussain Ahmad approached Mian Nawaz Sharif to boycott election because Musharraf had no intention to conduct free and fair election. It will be engineered and 'farce' election as commented by Benazir. Mian Nawaz Sharif disagreed with Mr. Qazi Hussain Ahmad. In the meanwhile, Benazir dialogued with Nawaz Sharif and convinced him to participate in election. Participation in election is the only one option to get rid of Musharraf. Otherwise again they will not be in position to legitimate their role. Election participation would compel Musharraf to comeback on democracy.

It's known fact that Benazir had left no option for Nawaz Sharif except to participate. After comprehensive discussion Nawaz Sharif agreed to participate in coming election (Nawaz, 2008). It's a known fact that first round of discussion between Nawaz Sharif and Benazir Bhutto failed because neither was convinced. Both political figured argued crossed the board. From Nawaz Sharif's perspective, election would be hijacked and nothing would be gained whereas, Benazir viewed that election in the ultimate source to have legitimate existence on continued arguments between both the decisions to fight electorate war against non-democratic forces. It has been observed that Election Commission has been deprived of autonomy and independence from 'Executive branch of the government'. This is one of the important reasons that Pakistan Election Commission is not enjoying genuine trust of the public. It is further observed that nondemocratic political culture has dominated election commission. On many occasions, the political leadership tried to manipulate role of election commission (Rais, 2008). The fear of mishandling of elections created mistrust among the political parties. Benazir considered election as the best expression of public opinion. Rigging in elections means simple negation of democracy. Transparent election is treated as to place flourished democracy. On $9^{\text {th }}$ December 2007, Nawaz Sharif announced that his party would participate in election.

\section{Elections Results}

2002 Provincial Assembly (Directly Elected Seats)

\begin{tabular}{|c|c|c|c|c|c|c|c|c|}
\hline \multirow{2}{*}{ Parties } & Punjab & & Sindh & & NWFP & & Balochistan & \\
\cline { 2 - 9 } & $\%$ & Seats & $\%$ & Seats & $\%$ & Seats & $\%$ & Seats \\
\hline PML (Q) & 33.5 & 129 & 7.7 & 11 & 14.5 & 6 & 19.7 & 10 \\
\hline PPP & 22.8 & 63 & 28.1 & 50 & 9.0 & 8 & 6.6 & 2 \\
\hline MMA & 5.7 & 9 & 8.1 & 9 & 26.3 & 48 & 16.6 & 13 \\
\hline PML (N) & 16.5 & 39 & - & - & 9.2 & 4 & - & - \\
\hline PML (F,J,Z) & 2.3 & 6 & 5.2 & 10 & - & - & - & - \\
\hline NA & 3.1 & 12 & 10.7 & 13 & - & - & 8.4 & 5 \\
\hline MQM & - & - & 12.0 & 32 & - & - & - & - \\
\hline ANP & - & - & - & - & 11.1 & 7 & - & - \\
\hline PPP-S & - & - & - & - & 9.8 & 9 & - & - \\
\hline JWP & - & - & - & - & - & - & 9.7 & 3 \\
\hline BNM & - & - & - & - & - & - & 6.8 & 3 \\
\hline BNP, BNDP & - & - & - & - & - & - & 6.9 & 3 \\
\hline PKMAP & - & - & - & - & - & - & 5.0 & 2 \\
\hline Other Parties & 2.3 & 0 & 20.0 & 1 & 5.3 & 1 & 4.9 & 0 \\
\hline Independents & 13.8 & 38 & 8.3 & 5 & 14.9 & 14 & 15.3 & 7 \\
\hline Total & 100.00 & 296 & 100.00 & 131 & 100.00 & 97 & 100.00 & 48 \\
\hline
\end{tabular}

Source: Data compiled by Andrew R. Wilder (Article: Election 2002: Legitimizing the Status Quo) using Election Commission of Pakistan Data 


\begin{tabular}{|c|c|c|c|c|c|c|c|c|c|c|c|}
\hline $\begin{array}{l}\text { Paovinact } \\
\text { assevesty }\end{array}$ & 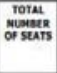 & $\begin{array}{l}\text { Result } \\
\text { Deccuato }\end{array}$ & 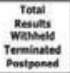 & $\begin{array}{l}\text { atsuly } \\
\text { Awarmed }\end{array}$ & $\begin{array}{c}\text { etcistiket } \\
\text { votues }\end{array}$ & $\begin{array}{l}\text { Total vorts } \\
\text { pouts }\end{array}$ & valio votes & $\begin{array}{l}\text { nesectiot } \\
\text { vorts }\end{array}$ & \begin{tabular}{|c|} 
Tuesour \\
of rotat \\
yorts \\
poutt \\
\end{tabular} & 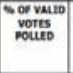 & 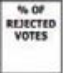 \\
\hline 1 & 2 & 3 & 4 & 5 & 6 & 7 & 8 & 9 & 10 & 11 & 12 \\
\hline $\begin{array}{l}\text { NWESP } \\
\text { Assembiy }\end{array}$ & 99 & 99 & 0 & 0 & 10500430 & 3559276 & 3469088 & 104344 & 33.46 & 97.47 & 2.93 \\
\hline $\begin{array}{l}\text { Purlab } \\
\text { Assiembly }\end{array}$ & 297 & 297 & 0 & 0 & 43780458 & 20979267 & 20371240 & 650293 & 47.55 & 97.10 & 3.10 \\
\hline $\begin{array}{l}\text { Shoth } \\
\text { Assembly }\end{array}$ & 130 & 130 & 0 & 0 & 19207129 & 8498911 & 8356719 & 175681 & 44.30 & 98.33 & 2.07 \\
\hline $\begin{array}{l}\text { Batochistan } \\
\text { Assembly } \\
\end{array}$ & 51 & 51 & 0 & 0 & 4520766 & 1493343 & 1368455 & 43545 & 33.29 & 91.64 & 2.92 \\
\hline TOTAL: & 577 & 577 & 0 & 0 & 78008783 & 34530797 & 33565502 & 973863 & 44.27 & 97.20 & 282 \\
\hline
\end{tabular}

Source: IT Wing- Election Commission of Pakistan Thursday, May 28, 2009.

Pakistan's Election Commission announced that election date would be extended as per date to given schedule. $18^{\text {th }}$ February will be new election date as proposed recommendation of majority number of political parties. Washington welcomed new democratic thinking and stated that independent media should be the observer for coverage election impartially to maintain transparent election, led to and Pakistan's positive image regarding as democratic state will be flourished, Even though, Musharraf's Pro-US friends argued that transparent election can maintain his status if national reconciliation is evolved among political parties and with him (Hirsh: 2007, Wright: 2007).

\title{
3. Electoral Campaign and Political Parties
}

Shadow of 9/11 event now demised which changed the national and international environment to a certain level. It has been observed that President Musharraf was being pressurized continuously to conduct election with transparency. Because of the general thinking that during Musharraf regime, the political parties were deeply stressed under the influential role of powerful spectrum of the intelligence agencies. It is a fact that since 1947, the political parties are instructed by the military establishment. In Zia regime, the Islamist-radical minded Jahadi Organizations had been given importance. The secular political parties had been victimized. Muslim League was again established within parliament in post 1985 although Non-Political Party' base election (Asim, 2004). It has been observed that Pervaiz Musharraf was interested in controlled democracy. So that democracy will be mixed with blend of dictatorship. Such sort of financial and political interests of the army for interfering in the political process of Pakistan are to be listed respectively.

\begin{abstract}
"The army has such a large monetary stake in the country that it will never allow a populist civilian government to interfere with the status quo. A civilian government may be permitted to continue only so far as it does not interfere with the financial interests of the army. Only a revolution may bring about a change in this state of affairs. Any civilian government brought into office by normal sedate democratic channels will neither have the strength, nor will it be permitted, to pursue a political or economic policy, which the military does not regard as conductive to its interests."(Khan, 1989)
\end{abstract}

On one occasion, George Bush stated that Islamabad should focus on transparent election. George Walven, Special Security Advisor to Washington said that honest and transparent election should be considered a pre-requisite for strengthening democracy. Unlike 2002 Election, Washington forcefully focused on transparent electorate procedure and maximum participation of the political leadership. It was noticed that low level of participation of the individuals and the party elites had been observed due to security threats. The political parties keep themselves to indulge in election campaign at minimum level. Apparently, it was perception that Pakistan Peoples' Party will win the 2008 Election but how many seats it will secure was not confirmed. In Punjab, Muslim League (N), Muslim League (Q), PPP, Jamat-e-Islami and others were in election race. It was predicted that Muslim League $(\mathrm{N})$ did efforts to work hard to vote bank divided between Muslim League (N) and (Q). In this situation PPP will get advantage. In last election, Mian Nawaz Sharif was not present and his voters were not assured but given tough time in some areas. Now circumstances were different. Muslim League (Q) with support of Pervaiz Musharraf was in challenging position. In Punjab, Pakistan People's Party (PPP) was sure for some conventional seats but having no expectations to win maximum seats. One view was staged that by 
utilizing Benazir Bhutto death card, PPP could be in the position to gain maximum number of seats. So, the party seats position was not easy to be predicted. Pakistan Tehrik-e-Insaf (PTI) and Jamat-e-Islami had boycotted 2008 Election. In Sind, it was the possibility that PPP will get majority because no other political party was in strong position to give tough time. Local parties in Sind were already limited to their specific constituents. MQM was in challenging mood before PPP only in urban areas. Because of the boycott of Jamat-i-Islami, the competition between PPP and MQM was open. Even for the formation of government in center, Musharraf arranged a political alliance between Muslim League (Q) and MQM and finally few members of PPP were snatched with heavy price. In this way a government set up was established. Now the circumstances for Mr. Musharraf were not as favorable as in past (Hussain: 2007, Jane: 2007). Also, in NWFP, the circumstances were now at moderate level as compared to last election. In 2002 election, MMA cashed Anti-US slogan and gained majority but its status as opposition party remained question mark. Secondly, now the emotional factor of the common man was at moderate level. It was assumed that historical legacy of ANP will be in better performance mood. PPP was sure only on specific seats, based on individual's constituencies.

In Baluchistan, the circumstances were not integrated. After Nawab Akbar Khan Bughti death, Baloch National Liberation Movement was strengthened, led by Nawab Talal Bughti and Nawab Barahmdad Bughti. Other Baloch Sardars including Mengal and Mari favored 'Azad Baluchistan'. The Baloch Sardars were not pleased with Muslim League (Q) because Nawab Akbar Bughti was not given protection as promised by Ch. Shujat Hussain and Syed Mushahid Hussain. It is a known fact that Musharraf did not follow commitments between Nawab Akbar Bughti and Mushahid Hussain. Electorate situation for MMA in Baluchistan was not favorable because it hard coalition with Muslim League (Q). Peoples Party and Muslim League $(\mathrm{N})$ were in better position to access Baloch Sardars because both leaders condemned Bughti episode and favoured to adopt dialogue for integration. Now the elections of Baluchistan were associated with these two main political parties. Besides this, individual constituencies, belonging to Sardar Tribal System were reserved as specific seats. Now Baluchistan politics was revolving around specific circumstances. Besides this, the national and international media was present to monitor election as to observe transparency during election campaign. US Secretary of State, Condoleezza Rice said, "Expected poll will be real test for Pakistan's commitment with extremism" (Hirsh, 2007). Further she said that the coming election will determine the future of democratization process in Pakistan.

\section{A Blow for Musharraf}

West openly viewed that Musharraf would have to face serious consequences in the case, elections are rigged. In this phase, Musharraf was mentally prepared to accept election results. Now a new electorate college (National Assembly + Provincial Assemblies) will elect Pervaiz Musharraf for next Presidency. So the coming electorate college was important for President Musharraf's future. On $18^{\text {th }}$ February 2008 , the elections were finally conducted. The official results were announced. PPP won 121 seats out of 342 in National Assembly. Muslim League (N) got 91 seats out of same number. PML (Q) secured only 54 seats. The pre-election environment after Benazir death formed reconciliation between PPP and Muslim League $(\mathrm{N})$. It was clear message for Musharraf that he would be out of political scene because both these parties got almost 2/3 majority in National Assembly. Awami National Party (ANP) got credible seats against Islamist Jamiat Ulma-i-Islam (Mulana Fazal-u-Rehman group) but both were in strong position to facilitate as ally party with Muslim League (N) or PPP. In Sind, PPP gained visible majority in rural areas but MQM secured its position in urban areas. For establishment of Federal Government, MQM was in better position to bargain and it could facilitate PPP in Sind. Although PPP won maximum number of seats yet coalition government was finally to be staged in Sind. In Punjab, dense populated area of Pakistan, Mian Nawaz Sharif (M. League) attained majority number of seats and Mr. Shabaz Sharif got obvious majority in Punjab. In NWFP, PPP joined secular party ANP for formation of government in province. In NWFP, the voters rejected Islamist coalition and preferred to vote moderate political party. It was a surprising situation that Muslim League (Q) got enough seats to form government but it failed to do so. PPP formed a coalition government in Baluchistan.

\section{Opposition to Musharraf's Policies}

Before election, Musharraf realized that in future he had to move with strong opposition which will not tolerate him as the President of Pakistan. In election scenario, Musharraf sponsored Muslim League (Q) failed to facilitate. The political observers concluded Muslim League (Q) failed due to Lal Masjid episode and rising militancy against Musharraf's extraconstitutional acts, favored U.S. forces and War on Terrorism. It had been observed that Musharraf's resignation was the only solution to many problems. On the other hand Musharraf bargained with PPP in terms of NRO Deal and continuity of his presidency. Musharraf rejected opposition call within parliament regarding resignation. He stated that he would 
continue to go ahead with new parliament in future. Musharraf's expectations were associated with Army to handle the opposition within parliament. After election, the dialogue discussion was started regarding impeachment of Musharraf like U.S President Richard Nixon. On the other side, one school of thought was not in favor of impeachment of Musharraf. The second group of politicians favored Musharraf's trial. Anyhow finally it was decided that Musharraf should be given complete dignified exit. At the last movement, Musharraf attempted to convince his foreign friends about his commitment with terrorism. It is notable feature that Musharraf was dragged but he had full support on some issues from Washington and Pakistan army. It had been observed that Musharraf's friends within Pakistan and across border did efforts to split the coalition figure of Muslim League (N) and PPP. Musharraf was told that coalition government between PPP and Muslim League $(\mathrm{N})$ scattered his regime. It has been observed that Musharraf was engaged to keep set aside. Muslim League (N) from PPP and further to weaken the civilian government. In fact the powerful state holders of the Pakistani establishment to repeat previous episodes like 1989-1993. In the presence of strong parliament, they will be affected and will be questioned. It is the main problematic concerned area of anti-democratic force. They were interested to save Musharraf and further to dominate the civilian government. Now again the conspiracy against the democratic institutions was prepared. It was obvious that Musharraf will be given 'safe exit' so as military led establishment can maintain its supremacy over the institutions. In result of successful dialogue between Muslim League (N) and PPP, the mutual signed agreement was taken place that democracy and institutions will be strengthened. Pakistan Peoples' Party as majority party in parliament will enjoy Prime Minister Office and Muslim League $(\mathrm{N})$ will play the role of the opposition and including Chief Minister Ship in Punjab. ANP as majority party in NWFP joined PPP for formation of government led government coalition in parliament and constituted Chief Minister Ship in the province. In Sind, PPP was in majority for formation of government within province with MQM. MQM has strong political mileage in Sind and along with parliament. With this formation, the coalition government in central and provinces were constituted. Murree Declaration was approached as 'historic agreement' for strengthening democratic institutions. Dr. Fahmida Mirza was elected Speaker National Assembly finally announced that Mr. Yousaf Raza Gillani will be the next $22^{\text {nd }}$ Prime Minister of Pakistan. Ch. Nisar Ahmad Khan was nominated as opposition leader. Important things that were coalition ministerial / cabinet included Muslim League ( $N$ ) and Pakistan PPP. Out of 24 Minister Cabinet, 11 Ministers were taken from PPP and 9 members were from Muslim League (N). Shah Mahmood Qureshi, Ch. Ahmad Mukhtar, Ishaq Dar, Rehman Malik and Nadeem Ghori were given important portfolio respectively as followed Foreign Minister, Defense Minister, Finance Minister, Interior Minister and Shipping Post. Mr. Baloor represented ANP in central cabinet and awarded Ministry of Railway. Rehman Malik reputed as bureaucrat former Additional Director General F.I.A. joined PPP. On the basis of technocrat seat, he was constituted as Interior Minister in Cabinet. A recent account reads" Pakistan is controlled and ruled by ashrafiya elites comprising, indomitable military complex, civil bureaucracy, higher judiciary, landed aristocracy and its cronies, industrialist-turned politicians, religious and spiritual leaders, media tycoons and some of their powerful employees, and unscrupulous businessmen. The economy of ashrafiya-controlled-Pakistan, thus, serves the interests of the privileged classes.

\section{Voter Turnout, 1970-2002 (Directly Elected Seats)}

\begin{tabular}{|l|c|c|c|c|c|c|c|}
\hline \multicolumn{1}{|c|}{ Province } & $\mathbf{2 0 0 2}$ & $\mathbf{1 9 9 7}$ & $\mathbf{1 9 9 3}$ & $\mathbf{1 9 9 0}$ & $\mathbf{1 9 8 8}$ & $\mathbf{1 9 8 5}$ & $\mathbf{1 9 7 0}$ \\
\hline Punjab & 46.3 & 39.8 & 47.1 & 49.6 & 46.5 & 60.1 & 66.5 \\
\hline Sindh & 36.8 & 31.3 & 28.2 & 43.3 & 42.4 & 44.4 & 58.4 \\
\hline NWFP & 33.2 & 27.8 & 34.6 & 35.7 & 33.9 & 40.6 & 46.8 \\
\hline Balochistan & 27.2 & 23.2 & 24.9 & 29.2 & 25.7 & 37.4 & 39.0 \\
\hline All Pakistan & 41.4 & 35.4 & 40.3 & 45.5 & 43.1 & 53.7 & 61.5 \\
\hline
\end{tabular}

Source: Data compiled by Andrew R. Wilder (Article: Election 2002: Legitimizing the Status Quo), taken from 2002 figures from Gallup Pakistan. www.gallup.com.pk

The ruling classes, representing only $2 \%$ of entire population, own $95 \%$ of national resources" (Haq, 2012).

It was observed that neither a single political event has been examined in the political history of Pakistan since creation except after 2008 Election when two extreme opponents, Muslim League (N) and Pakistan People's Party joined coalition government. Restoration of judiciary was the mutual agreed formula between PPP and Muslim League Nawaz Group. It is a fact that both these political parties had been remained rivals to each other's. Zulfiqar Ali Bhutto nationalized industry and Mian Muhammad Sharif was affected. Later on, Zia-ul-Haq imposed Martial Law and during 1985 election, Mian Nawaz Sharif was fully financially and politically supported whereas, Mrs. Benazir Bhutto was 
politically sabotaged. After Zia, the anti-PPP forces formed political alliance Islami Jahmori Itihad (IJI) to minimize the political leverage of PPP in 1988 election. Since 1988 to 1996 and then to 1999, these two political parties had played as set staged role, by the supremacy of the institutions. The military led establishment interested to dominate civilian regime. With this background, it was said that this was the historic movement when cabinet Muslim League (N) + PPP was formed after 2008 election. In this regard, one group argued that both parties had learnt lesson from the ruined history. Few politicians stated that allied cabinet of both parties was a positive step towards institutionalization process but apart from it, the coalition government had to face challenges in future which will determine the status of this alliance. Now others said that alliance is better but they drawn pessimistic picture of this bright time oriented alliance. In this regard, some various sorts of perceptions were examined and interpreted. First important challenge before the coalition government was restoration of the judiciary, suspended and sacked by Mr. Pervaiz Musharraf. Mr. Zardari after Murree Declaration said that a constitutional reform based package had been introduced which had been thoroughly examined along with its political features. In the result of this discussion, it was framed that coalition government will introduce $18^{\text {th }}$ amendment and regarding restoration of judiciary. After formation of government, it was hoped that judiciary will be restored in dignified way. In meanwhile, the NRO deal was the most important challenge before judiciary. Asif Ali Zardari has sought to assure those agitating for the judges' reinstatement that restoration would come in due course of time. Nawaz Sharif himself blamed U.S. government, actively discouraging such restoration. Now the drift was going to appear on scene between Muslim League (N) and PPP. Many observers focused on respect for judicial independence, key strengthening feature for sustaining democratic credibility. In this way, democratic credible institutions were revalued and strengthened. Pakistan's Federal Law Minister stated, "Musharraf November 2007 independent judiciary was taking shape."

\section{Conclusion}

Since Pakistan's independence, 'Democracy' still has not been out of excuse from legitimacy. Pakistan has seen democracy in different terms and conditions. During Ayub Khan and Zia-ul-Haq regimes, democracy had been introduced according to requirement. In Musharraf regime, controlled democracy phenomenon had been flourished and parliament was kept under control of the military establishment. It is undemocratic tendency that Mr. Shaukat Aziz, having no political background and no political party affiliation had been nominated Prime Minister of Pakistan. Mr. Shaukat Aziz was a 'banker' and was in good book of the military establishment. Respectively, the parliamentarian party, Muslim League (Q) did not bother to argue before the military establishment. Musharraf implemented National Security Council (NSC) to check over parliament. Although, Musharraf engaged scenario into war against terrorism yet he attempted to introduce new sort of political thinking after election. Local Government Ordinance and National Security Council were milestone efforts, political impacts over Pakistan. It is the history of Pakistan; every dictator introduced Local Government System to access common man. Ayub Khan introduced Basic Democracy (BD) System. Non-party local government election was scheduled in Zia-ul-Haq era. In same the manner, Musharraf framed Local Government System on non-political party basis. It is also a fact that like Zia-ul-Haq, Musharraf tried to establish National Security Council. During second tenure of Nawaz Sharif, General Jahangir Karamat had given the idea of National Security Council. He had to take back his programme because of facing serious criticism from civilian government. Now this time, Musharraf repeated the idea of National Security Council (Jaspal, 2002).

It had been observed that all important issues had been dominated by the military establishment. Lal Masjid (Red Mosque) and Bughti Killing were the decisions, influence by the military establishment. Pervaiz Musharraf ignored the dialogue process in both cases and the state had to face security challenges. The international media projected both cases against Pakistan. As to take perception, it will be rightly said that military establishment adopted forced mythology to attain result which contradictory to democratic norms and values. With passage of time, the political scenario was changed and political power was transferred to new civilian government. Challenges before new parliament were tremendous and were fully exhausted. Issue of terrorism and Baluchistan crisis were at distortion level. Continuous suicide bombing and massive killing in Karachi had faded that economic prosperity of the state. It was surprised that new blend of government (PPP+ Muslim League $(\mathrm{N})$ was unique political alliance in the shadow of charter of democracy and policy of 'Reconciliation'. Expectations from this unique political alliance were high but complications were still present. On issue of restoration of Judiciary, the alliance was expired and Muslim League $(\mathrm{N})$ followed the option of Long-March to restore judiciary, resulted positive. Now PPP government had to face judiciary tussle and political separation from Muslim League (N) PPP formed political alliance with ANP, Muslim League (Q), Jamiat-e-Ulma Islam (F) Fazul-ur-Rehman group and Muthadia-Qaumi Movement (MQM- Altaf Group). With this new political set up, the civilian government introduced political agenda. One change was staged, caused restoration of 1973 constitution. PPP government introduced $18^{\text {th }}$ 
Amendment which changed the identical features of the system of government. Prime Minister Office was empowered as compared to president office. The $18^{\text {th }}$ Amendment redesigned the functions of the federal government and provincial governments. Since independence, the civilian governments were fighting for democracy and institutionalization process. 2008 election had revamped Musharraf legacy and new government with unique political alliance had taken up the political matters. New government had to face internal and external challenges like issue of extremism and Baluchistan crisis.

Apart from this the declining economic parameters were terrible for the government. Unfortunately the previous government failed to grip over these matters but new hopes were generated regarding to channelize resources for stabilization process. The elected government had to show mature democratic behavior for smooth institutionalization process. 'Charter of Democracy' was a positive development which ensured principal of co-operation and co-ordination among the political forces. It was expected that lesson from history will bring responsibility to hold high offices. It was hoped that the coalition government will readdress the central-province relationship. The political observers argued that the political leadership had to show greater political capacity to accommodation uneven invest. The dreams were complex and participation level was not meaningful. The spirit of 'charter of democracy' collapsed as the unique political alliance was broken and Nawaz Sharif decided to play role of the opposition. The tussle started with the issue of sacked judges. Mr. Asif Ali Zardari was not interested to restore Chief. Justice, Ch. Iftikhar due to some reservations whereas Mian Nawaz Sharif stated that judiciary issue was already settled in charter of Democracy and Boharban Declaration. It should be considered that simple negation of the agreement Asif Ali Zardi said, "Agreement was not a Holy Quran or Hadith."

The struggle for democracy and institutionalization process is a matter of understanding the democratic values and norms. Tolerance and commitment for strengthening the institutions are first and foremost elements to lead democracy in transitional phase. A unified understanding towards challenges will ensure government for an institutional and democratic regime. The government has to understand that negotiated agreement will introduce positive changes to secure democracy and institution.

\section{References}

Andrew, W. (2002). Article: Election 2002: Legitimizing the Status Quo), taken from 2002 figures from Gallup Pakistan. www.gallup.com.pk

Asim, Y. (2004, April 2). NSC to Help Flourish Democracy: Jamali. The News Election Commission of Pakistan IT wing. (2009, May 28). www.ecp.gov.pk

Haq, I. (2012, June 9). Pakistan is Controlled and Ruled by the Elites. http://alaiwah.wordpress.com/2012/06/09/pakistan-is-controlledand-ruled-by-the-elites/

Hirsh, M. (2007, December 28). Is Rice Rushing to Elections?. Newsweek

Hussain, I. (2007, August 19). Deal-ing a Bad Hand. Daily Times.

Jane, P. (2007, November 11). Bhutto's Persona Raises Distrust, As Well As Hope. New York Times

Jaspal, N. (2002). National Security Council: Implications For Pakistan's Political System. http://ipripak.org/articles/newspapers Inationalsecurity.shtml.

Jill, M. (2007, December 12). Pakistan Islamic Bloc Suspended. BBC News

Khan, M. (1989, April 3-5). 1973 Constitution - The Founding of the Federation, an unpublished paper read at a seminar: "The Heritage of Prime Minister Bhutto," in Karachi. note 10.

Mazhar, A. (2005, January 7). MMA's Anti-Musharraf Campaign a Damp Squib?. Friday Times

Nawaz Sharif, M. (2008, January 1). The Future Pakistan Deserves. Washington Post

Rais, R. (2008). Pakistani Elections: Troubled Legacy. http://www.learningace.com/doc/229265/1bf6ed6087217014aa7625c4 ed8e4c3f/raiselections

(2007, December 31). U.S. Presses Pakistan to Go Ahead With January 8 Vote, Reuters

(2007, November 17). U.S. Trying to Revive Musharraf-Bhutto Deal, Reuters

Wallace, B. (2007, December 3). Skepticism Tinges Support for Bhutto. Los Angeles Times http://articles.latimes.com/2007 /dec/03/world/fg-bhutto3

Witte, G. (2007, December 23). Pakistan's Islamic Parties Struggle for Support. Washington Post http://www.washingtonpost.com/wpdyn/content/article/2007/12/22/AR2007122200387.html

Wright, R \& Kesser, g. (2007, December 29). U.S. Strives to Keep Footing in Tangled Pakistan Situation. http://www.washingtonpost. $\mathrm{com} /$ wp-dyn/content/article/2007/12/29/AR2007122901490.html 